\title{
High fecundity of hybrids between the sympatric snail species Viviparus ater and V. contectus (Gastropoda: Prosobranchia)
}

\author{
HANS TRÜB \& GEORG RIBI* \\ Zoological Museum, University of Zürich, Winterthurerstr. 190, 8057 Zürich, Switzerland
}

\begin{abstract}
Interspecific crosses between Viviparus contectus males and $V$. ater females were successful (53 per cent of intraspecific $V$. ater fecundity), whereas the reverse combination was almost sterile (1.2 per cent of intraspecific $V$. contectus fecundity). The hybrid offspring had a high survival rate ( 99 per cent in the first year) and a male-biased sex ratio ( 84 per cent males). $\mathrm{F}_{1}$ hybrids were fertile inter se and in all six backcross combinations tested. Some of the backcrosses had fecundities similar to intraspecific control crosses. Hybrid females produced more offspring in backcrosses with $V$. contectus males than with $V$. ater males, suggesting that the higher fecundity of $V$. contectus as compared with $V$. ater can be inherited paternally. The male-biased sex ratio of hybrids suggests that the female is the heterogametic sex in Viviparus. The male-biased sex ratio and the high fecundity of hybrids of both sexes in backcrosses are compatible with Coyne's (Coyne, J. A. 1992 Nature, 355, 511-515) hypothesis of a composite nature of Haldane's rule. The high fecundity of hybrids also implies that introgression may occur in natural populations.
\end{abstract}

Keywords: Haldane's rule, hybrid fecundity, introgression, species barriers.

\section{Introduction}

The reproductive success of hybrids when backcrossed to their parental taxa has two important implications. First, if hybrids are fertile, gene introgression may occur. This can be a problem when species are introduced into new habitats (Echelle \& Connor, 1989). Secondly, the fecundity of hybrids is usually lower than that of the parental taxa, which will result in selection against hybrids. Selection against hybrids is assumed to be a key factor in speciation, because reduced fitness of hybrids is an important isolating mechanism (White, 1978). Selection against hybrids is also a precondition for reinforcement of sexual isolation, which is thought to be important after secondary contact of incipient species that have formed in allopatry (Noor, 1995).

The freshwater snails Viviparus ater (Christofori \& Jan) and $V$. contectus (Millet) are sympatric in lakes and streams of northern Italy and hybridize in Lake Garda; allozyme patterns are compatible with the hypothesis of gene introgression between the two species in both directions (Porter \& Ribi, 1994; Katoh \& Ribi, 1996). The two species can be distin-

${ }^{*}$ Correspondence. E-mail; ribi@zoolmus.unizh.ch guished easily: $V$. ater has a more elongated shell, whereas that of $V$. contectus is wider and the whorls are more distinct. Both species attain $30-40 \mathrm{~mm}$ shell height. Viviparus ater has nine and $V$. contectus has seven chromosomes in the haploid set, and chromosomes suggested to be involved in Robertsonian mechanisms make up approximately one-third of the total chromosomal length of both species (Rainer, 1963). The sexes are separate and, in males, the right tentacle is enlarged and is used for sperm transfer to the female (Fretter, 1953). The sex of adults can be identified easily by the shape of the right tentacle: slender and pointed in females, thickened and rounded in males. Both $V$. ater and $V$. contectus brood offspring internally. Viviparus ater first reproduce at 1.5-2 years old, and remain reproductive throughout their lives. Offspring (7-11 mm in shell diameter) are born throughout the summer but mostly in May and June. Individuals over 10 years old have been found (Ribi et al., 1986), and the mean fecundity in Lake Zürich is 20 offspring per female per year (Ribi \& Gebhardt, 1986). Viviparus contectus first reproduce at 1 year old. They have smaller (4-7 $\mathrm{mm})$ and more numerous offspring (30-60 female $\left.\mathrm{f}^{-1} \mathrm{y}^{-1}\right)$ and tend to have a 
shorter life span than $V$. ater (Trüb, 1990). Both species hibernate in the sediment.

Matings between $V$. ater and $V$. contectus have been observed frequently, both in nature (Trüb, 1990) and in mating experiments (11 per cent of matings; Ribi \& Porter, 1995). From electrophoretic data of natural populations suggesting that introgression between the two species may have occurred (Porter \& Ribi, 1994), we expected that crosses between $V$. ater and $V$. contectus and their hybrids should not be completely sterile. On the other hand, given the extensive differences between the two species, we expected the fecundity of such crosses to be low. In this paper, we measure the success of interspecific crosses and the fecundity of hybrids between $V$. ater and $V$. contectus.

\section{Methods}

Relative hybrid and backcross fecundities were estimated in a breeding experiment. Viviparus ater were collected by scuba diving in 1986 at Lazise on Lake Garda, Italy, and also from Goldbach, Lake Zürich, Switzerland (where $V$. contectus is absent). Viviparus contectus was collected at the same time at Lazise. We used only snails with shell shapes typical of $V$. ater or $V$. contectus. Nevertheless, unrecognized hybrids may have been present in the samples from Lake Garda. Although first generation hybrids can usually be recognized by their shell shape, some individuals may closely resemble $V$. contectus, and backcross hybrids are often indistinguishable from the parent species with which they share the majority of genes. As the frequency of hybrids in natural populations is low $(<1.4$ per cent, Katoh \& Ribi, 1996), we do not think that any hybrids that may have been used in the experiment would have significantly biased the results.

Offspring were obtained from females and reared to reproductive age in individual cages to obtain virgin females for subsequent crosses. Cages for juveniles were $17 \mathrm{~cm}$ high by $7 \mathrm{~cm}$ diameter cylinders, made of plastic cloth on rigid plastic frames. When snails began to reach maturity after the first season, they were caged in all reciprocal interspecific combinations, with controls pairing conspecifics within source populations (Table 1, upper left). Cages for adults were cones $21 \mathrm{~cm}$ high with a $28 \mathrm{~cm}$ basal diameter (Trüb, 1990). Two males and two females occupied each of six cages per cross. Because we expected a low fecundity of females in interspecific crosses, we used two pairs per cage to increase the probability of obtaining hybrid offspring. To check for the possibility of partheno- genetic reproduction, 24 virgin females of each source population were caged without males for 4 years (four females per cage). All cages were submerged $3 \mathrm{~m}$ in Lake Zürich, examined weekly by scuba diving and unclogged by scraping away excess algae; the snails were fed with cooked carrots. Cages for adults were scanned for mating pairs and, for 2 years, offspring were counted and removed from each cage.

$F_{2}$ and backcross generations followed the same protocol, except that the cages contained only one pair each, and small offspring numbers from some $\mathbf{F}_{1}$ crosses precluded a symmetrical design. There were two types of hybrid $\times$ hybrid crosses and 11 types of backcrosses (Table 1).

The offspring production of crosses using $V$. ater from Lake Garda was compared with those using $V$. ater from Lake Zürich by a two-way ANOVA testing

Table 1 Crossing scheme of Viviparus ater, V. contectus and their hybrids

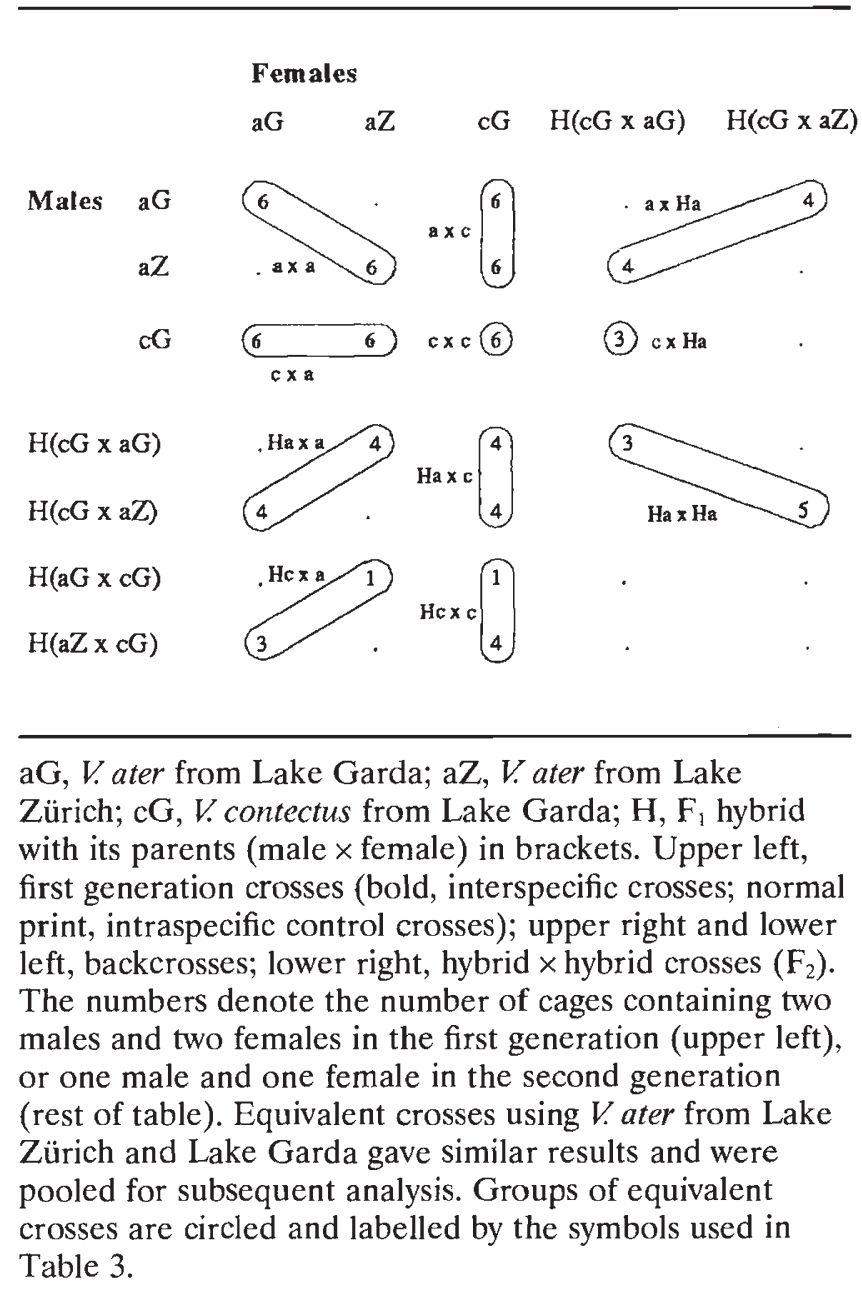


for the effects of the lake and the type of cross. The data were log-transformed to normalize the distributions. Crosses using $V$. ater from Lake Zürich did not differ significantly in offspring production from crosses using $V$. ater from Lake Garda (Table 2). Therefore, the data of equivalent crosses using $V$ ater from the two lakes were pooled for subsequent analysis. A one-way ANOVA testing for an effect of the different types of crosses was performed, and differences between different crosses were judged by Fisher's protected least significance difference (PLSD) (Sokal \& Rohlf, 1995).

During winter the snails buried themselves in the sediment layer (approximately $5 \mathrm{~cm}$ thick) that was provided in the cages. Four females died during the study (two $V$. contectus of intraspecific control crosses, one $V$. ater female of the $\mathrm{Ha} \times \mathrm{a}$ cross, and one hybrid female of the $\mathrm{a} \times \mathrm{Ha}$ cross). Their offspring were omitted from consideration.

Offspring survival was estimated by counting the snails still alive in the rearing cages at the end of the breeding season.

Table 2 ANOVA table for the effects of the lake from which Viviparus ater were derived (Lake Garda or Lake Zürich) and of the type of cross (as shown in Table 3), on the number offspring produced. Offspring numbers were log-transformed before analysis

\begin{tabular}{lrrrr}
\hline Effect & d.f. & MS & \multicolumn{1}{c}{$F$} & \multicolumn{1}{c}{$P$} \\
\hline Lake & 1 & 0.138 & 2.402 & 0.1276 \\
Cross & 7 & 1.879 & 32.765 & $<0.0001$ \\
Lake $\times$ Cross & 7 & 0.011 & 0.186 & 0.9871 \\
Residual & 49 & 0.057 & & \\
\hline
\end{tabular}

In some cases females prematurely released embryos that were still in the egg. Such eggs, which appeared as white balls of a few $\mathrm{mm}$ in diameter, were recorded whenever observed.

\section{Results}

Mating pairs were observed for each type of cross. Females reared without males never reproduced.

The average number of offspring per female in 2 years for each cross is shown in Fig. 1. Offspring numbers in each year are given in Table 3. The control crosses showed that $V$. contectus females produced twice as many offspring as $V$. ater females (Fisher's PLSD, $P=0.0013$ ). Crosses between species had fewer offspring than intraspecific controls. Viviparus contectus males $\times V$. ater females had 53 per cent of normal $V$. ater offspring production (Fisher's PLSD, $P=0.0075$ ), whereas the reciprocal combination produced very few offspring, 1.2 per cent of observed $V$. contectus reproduction (Fisher's PLSD, $P<0.0001$ ). There was thus a strong asymmetry in hybrid production between the two reciprocal combinations (Fisher's PLSD, $P<0.0001$ ).

$\mathrm{F}_{1}$ hybrids were fertile inter se and in all of the six backcross combinations tested (Table 3 ). Two backcross combinations could not be tested because no female hybrids were obtained from the $V$. ater males $\times V$. contectus female crosses. Females in hybrid $\times$ hybrid crosses had reduced fecundities relative to those of intraspecific control crosses of both species (Fisher's PLSD, $P=0.0002$ for $V$. ater, $P<0.0001$ for $V$. contectus).

The fecundity of $V$. ater females backcrossed to hybrid males was not significantly different from that of intraspecific controls (Fisher's PLSD, $P=0.51$

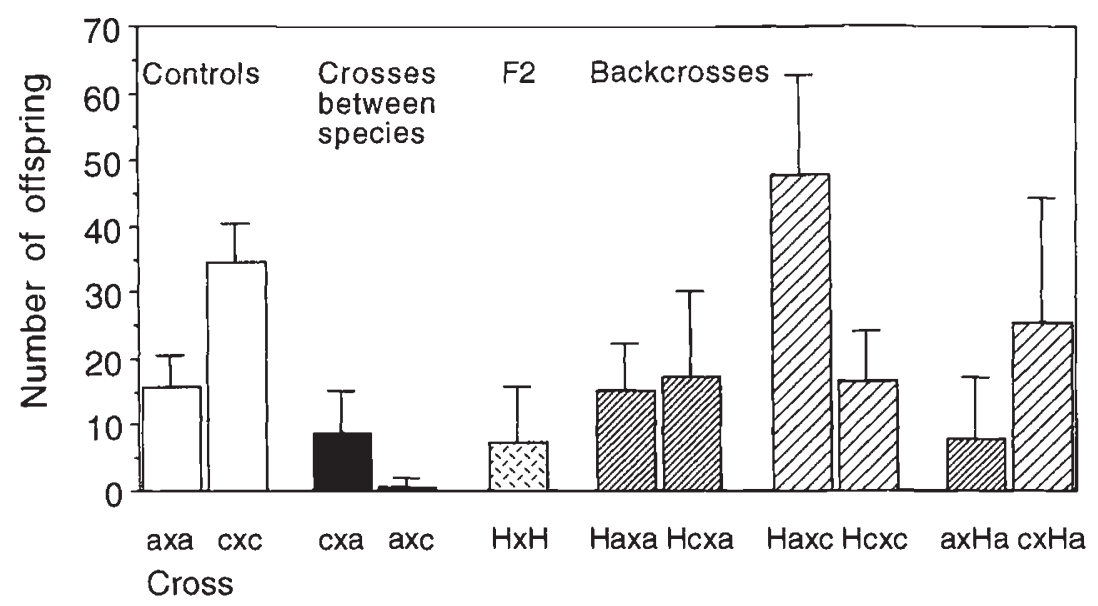

Fig. 1 Mean annual fecundity (number offspring per female averaged over two breeding seasons) of the different crosses (male $\times$ female). Error bars are one standard deviation. a, Viviparus ater; $\mathrm{c}, V$. contectus; Ha, hybrids whose mothers were $V$. ater; $\mathrm{Hc}$, hybrids whose mothers were V. contectus. White bars, intraspecific control crosses; black bars, crosses between species; checkered bar, hybrid $\times$ hybrid crosses; dark-hatched bars, backcrosses of hybrids to V. ater; light-hatched bars, backcrosses of hybrids to $V$. contectus. 
Table 3 Annual number of offspring per female (average \pm standard deviation), offspring survival during the first summer and sex ratio of surviving offspring for the different crosses

\begin{tabular}{lccccccccccc}
\hline Cross (male $\times$ female) & $\mathrm{a} \times \mathrm{a}$ & $\mathrm{c} \times \mathrm{c}$ & $\mathrm{c} \times \mathrm{a}$ & $\mathrm{a} \times \mathrm{c}$ & $\mathrm{Ha} \times \mathrm{Ha}$ & $\mathrm{Ha} \times \mathrm{a}$ & $\mathrm{Hc} \times \mathrm{a}$ & $\mathrm{Ha} \times \mathrm{c}$ & $\mathrm{Hc} \times \mathrm{c}$ & $\mathrm{a} \times \mathrm{Ha}$ & $\mathrm{c} \times \mathrm{Ha}$ \\
\hline Number of surviving females & 24 & 10 & 24 & 24 & 8 & 7 & 4 & 8 & 5 & 7 & 3 \\
Number of offspring per female $\dagger$ & & & & & & & & & & \\
$\quad$ & 16.9 & 33.7 & 12.9 & 0.7 & & & & & & \\
& \pm 5.8 & \pm 6.7 & \pm 6.7 & \pm 1.9 & & & & & & \\
& & & $76 \%$ & $2 \%$ & & & & & & & \\
1989 & 14.4 & 35.7 & 4.4 & 0.3 & 1.1 & 13.4 & 8.0 & 42.9 & 10.4 & 1.8 & 11.7 \\
& \pm 3.7 & \pm 5.2 & \pm 2.8 & \pm 0.6 & \pm 1.2 & \pm 8.1 & \pm 6.5 & \pm 10.8 & \pm 4.0 & \pm 1.7 & \pm 17.7 \\
1990 & & & $30 \%$ & $0.8 \%$ & $79 \%$ & $47 \%$ & $127 \%$ & $31 \%$ & & & \\
& & & & & 13.6 & 17.3 & 29.3 & 56.0 & 22.6 & 15.1 & 38.7 \\
& & & & & \pm 8.0 & \pm 5.4 & \pm 6.4 & \pm 17.8 & \pm 5.3 & \pm 8.8 & \pm 7.1 \\
Offspring survival (\%) & 96.2 & 93.4 & 99.5 & 100 & 86 & 95 & 75 & 88 & 100 & & 86 \\
Sex ratio of offspring (\% males) & 50.5 & 53.4 & $79 * * *$ & $100 * * *$ & 83 & 45 & 100 & 59 & 50 & & 48 \\
$N$ & 451 & 409 & 155 & 18 & 7 & 40 & 4 & 75 & 18 & & 29 \\
\hline
\end{tabular}

a, Viviparus ater; c, V. contectus; Ha, hybrids whose mothers were V. ater; Hc, hybrids whose mothers were V. contectus. Below the standard deviation is the percentage of the average intraspecific fecundity of the females used in the cross (in backcrosses, the percentage was calculated using controls of the previous year). Sex ratios significantly different from 1:1 $\left(\chi^{2}\right.$-test, $\left.P<0.0001\right)$ are denoted by ${ }^{* * *} . N$, number of offspring used to determine the sex ratio.

$\dagger$ Average \pm standard deviation and as percentage of intraspecific control crosses.

and $P=0.55$ for hybrids with $V$. ater and $V$. contectus mothers).

There is evidence suggesting that fecundity may in part be inherited paternally in Viviparus. We can use the fact that $V$. contectus has twice the fecundity of $V$. ater in intraspecific crosses to analyse the fecundities of different types of backcrosses. Viviparus contectus females, when backcrossed to hybrid males whose mothers were $V$. ater and whose fathers therefore were also $V$. contectus, had fecundities typical of intraspecific $V$. contectus crosses (Fisher's PLSD, $P=0.83$ ). However, in backcrosses with hybrid males whose mothers were $V$. contectus and whose fathers were $V$. ater, the fecundity was significantly reduced with respect to intraspecific $V$. contectus controls (Fisher's PLSD, $P<0.0077$ ). This suggests paternal inheritance of fecundity in $V$. contectus.

Hybrid females backcrossed to males of either species had somewhat lower fecundities relative to intraspecific control crosses in the first year, whereas in the second year their fecundities were close to those of the intraspecific control crosses of the species of the male (Table 3). Hybrid females, when crossed to $V$. contectus males, produced more than twice as many offspring than hybrid females crossed to $V$. ater males (Fisher's PLSD, $P=0.0011$ ). This is additional evidence that the difference in fecundity between the two species may be inherited paternally.
Juvenile survival during the first summer was $>93$ per cent for intraspecific control crosses, $\geq 99$ per cent in $F_{1}$ hybrids, and $\geq 75$ per cent in $F_{2}$ and backcrosses (Table 3). In backcrosses, we observed 18 aborted eggs during 1990. Because diving took place once a week and aborted eggs decomposed within 1-2 days, the total number of aborted eggs was probably higher. If an average decomposition time of 1.5 days is assumed, the total number of aborted eggs would have been 84 , compared with 933 live offspring from backcrosses in 1990. Hence, a frequency of aborted eggs of between 5 and 10 per cent can be estimated. This suggests that there is selection against backcross hybrids before they are born.

The sex ratio of intraspecific control crosses was near 1:1 for both species, but biased towards males in $\mathrm{F}_{1}$ hybrids (84 per cent males, $\chi_{1}^{2}=82.3, P<0.001$, Table 3). A male-biased sex ratio appeared to persist into the $F_{2}$, but could not be tested because of small sample sizes. No sex ratio bias was detected in backcrosses (Table 3).

\section{Discussion}

The main results of the present study are, first, that $V$ ater and $V$. contectus produce viable hybrids, and that both male and female hybrids are fertile; 
secondly, that there is a strong asymmetry in the fecundity of reciprocal interspecific crosses, and a male-biased sex ratio in the $F_{1}$ hybrids.

The ease with which the two species can be crossed and the relatively high fecundity of the hybrids is unexpected. In Drosophila, successful crosses between species, although frequent, have been restricted to pairs of closely related species (Bock, 1984). In Europe, five species of Viviparus are presently recognized, and several additional taxa of uncertain status have been mentioned (Bourgignat, 1862). Of all these, $V$. ater and $V$. contectus may be the most distinct species-pair of the group, and they have been suggested as belonging to different genera (Chernogorenko, 1992). They have different shell morphology (Franz, 1932), different chromosome numbers (Rainer, 1963), and Nei's genetic distances between two $V$. ater populations and three $V$. contectus populations varied between 0.600 and 0.773 (S. Oertli, unpubl. data). In Drosophila, most species pairs with genetic distances of $\geq 0.6$ had a postzygotic isolation index of 0.75 or 1 , meaning that at least three out of four hybrid sexes obtainable from both reciprocal crosses were either completely sterile or completely inviable (Coyne \& Orr, 1989). Viviparus ater and $V$. contectus have a sterility index of 0.25 , because one cross $(V$ ater male $\times V$. contectus female) produced fertile male but no female hybrids, whereas the reciprocal cross produced fertile hybrids of both sexes.

Although allozyme data from sympatric populations of $V$. ater and $V$. contectus are compatible with the hypothesis of gene introgression, data from allopatric populations of the two species could be explained either by past introgression and subsequent range expansion of one or both of the species, or by shared ancestry of alleles (Katoh \& Ribi, 1997). The results of the present study do not allow us to distinguish between the two possibilities, but they do show that introgression cannot be ruled out. Because the two species often mate with each other in nature (Trüb, 1990), and hybrids have been found in natural populations (Katoh \& Ribi, 1996), the demonstration that hybrids are fertile in backcrosses with both parental species makes introgression a real possibility. Barton \& Bengtsson (1986) showed that genes not subject to sexual selection may, in theory, easily introgress from one species into another unless the fecundity of hybrids is very low. Previous work on Viviparus showed that behavioural patterns and ecological conditions of the two species, where they co-occur, do not constitute effective barriers to introgression (Porter \& Ribi, 1994; Ribi \& Porter, 1995). The low mortality of hybrids after birth and their relatively high fecundity in many of the backcrosses reported in this paper suggests that introgression may indeed be substantial, especially in places where one species is more abundant than the other (Porter \& Ribi, 1994).

We nevertheless found evidence of selection against hybrids: (1) a reduced fecundity of interspecific crosses; (2) a male-biased sex ratio of $F_{1}$ hybrids; (3) abortion of embryos in backcrosses; and (4) a reduced fecundity of hybrids in some of the backcrosses. Of these, the first is by far the most important, especially in the $V$. ater male $\times V$. contectus female cross, which proved to be almost sterile.

According to Haldane's rule (Haldane, 1922), which states that it is usually the heterogametic sex that is rare or absent among hybrids, the heterogametic sex in Viviparus should be the females, because the sex ratio of hybrids was male-biased. Preliminary results of an investigation of both sexes indicate the existence of heteromorphism in females on chromosome 8 in $V$. ater and on chromosome 6 in $V$. contectus (J. Barsiene, unpubl. data).

Coyne (1992) suggested that Haldane's rule is a composite phenomenon that requires separate explanations for hybrid inviability and hybrid sterility. In a recent review Wu et al. (1996) identified three different forces affecting hybrid fitness reductions in animals. Table 1 of their paper shows that species with heterogametic females (birds and Lepidoptera) follow Haldane's rule with respect to hybrid inviability in 90 per cent of reported cases. In the case of hybrid sterility the match is 100 per cent. Assuming that in Viviparus the females are the heterogametic sex, they are following Haldane's rule with respect to viability only: the sex ratio of hybrids was male-biased (84 per cent of hybrids were male). There appears to be no asymmetry with respect to hybrid fecundity. Both male and female hybrids are fertile, and fecundity differences between different backcrosses are related to the species of the non hybrid parent ( $V$. ater or $V$. contectus), and not to the sex of the hybrid (both male and female hybrids produced similar numbers of offspring when backcrossed to the same parental species) for the three types of hybrids obtained from the interspecific crosses. The observation that there is an asymmetry in hybrid viability but not in hybrid fertility is in agreement with the notion of a composite nature for Haldane's rule. However, it contrasts with previous data in that no such case has yet been reported in species with heterogametic females.

Viviparus contectus females had a lower fecundity in interspecific crosses than $V$. ater females. This may be because of a chromosomal or developmental 
limitation to hybridization that is more pronounced in $V$. contectus females than in $V$. ater females. In conclusion, we think that $V$. ater and $V$. contectus are genetically different from each other to such a degree that they are unlikely to merge, even if substantial introgression should occur.

\section{Acknowledgements}

We thank H. Maag for constructing the cages and for diving; B. Tanner and J. Sonderegger for help with the field work in Lake Garda; and M. Katoh, A. Porter, B. Porter, P. Ward and two reviewers for helpful comments on the manuscript. This work was supported by Swiss NSF grant 31-25310.88 to G.R.

\section{References}

BARTON, N. H. AND BENGTSSON, B. O. 1986. The barrier to genetic exchange between hybridising populations. Heredity, 56, 357-376.

BOCK, 1. R. 1984. Interspecific hybridization in the genus Drosophila. Evol. Biol., 18, 41-70.

Bourgignat, M. J. R. 1862. Notice sur les Vivipara d'Europe. Les Spicilèges Malacologiques. In: Extrait de la Revue et Magasin de Zoologie, pp. 123-133. Chez Baillière et Fils, Librairies, Rue Hautefeuille, 19, Paris.

CHERnOGorenKo, E. v. 1992. On the species composition of Viviparids (Gastropoda, Viviparidae) in Europe and Western Asia. Harv. University of Mus. Comp. Zool. Spec. Occas. Publ., 11, 1-26.

COYNE, J. A. 1992. Genetics and speciation. Nature, 355, $511-515$.

COYNE, J. A. AND ORR, H. A. 1989. Patterns of speciation in Drosophila. Evolution, 43, 362-381.

ECHELlE, A. A. AND CONNOR, P. J. 1989. Rapid, geographically extensive genetic introgression after secondary contact between two pupfish species (Cyprinodon, Cyprinodontidae). Evolution, 43, 717-727.

FRANZ, v. 1932. Viviparus: Morphometrie, Phylogenie und Geographie der europäischen, fossilen und rezenten Paludinen. Denkschriften der Medizinisch-Naturwissenschaftlichen Gesellschaft zu Jena (Gustav Fischer), 18, $1-160$.
FRETTER, V. 1953. The transference of sperm from male to female prosobranch, with reference, also, to the pyramellids. Proc. Linn. Soc. Lond., Sess. 164, 1951-52, 217-224.

HALDANE, J. B. S. 1922. Sex ratio and unisexual sterility in hybrid animals. J. Genet., 12, 101-109.

KATOH, M. AND RIBI, G. 1996. Genetic evidence for natural hybridization and apparent introgression between freshwater snail species (Viviparus ater and $V$. contectus). J. Evol. Biol., 9, 67-82.

KATOH, M. AND RIBI, G. 1997. Genetic variation in sympatric and allopatric populations of hybridizing freshwater snail species (Viviparus ater and V. contectus). J. Moll. Stud. (in press).

NOOR, M. A. 1995. Speciation driven by natural selection in Drosophila. Nature, 375, 674-677.

PORTER, A. AND RIBI, G. 1994. Population genetics of Viviparus (Mollusca: Prosobranchia): homogeneity of $V$. ater and apparent introgression into $V$. contectus. Heredity, 73, 170-176.

RAINER, M. 1963. Vergleichende Chromosomenmessungen an Viviparus-Arten (Prosobranchia). 23. Jb. schweiz. gesell. Vererbungs. Soc. suisse de génétique (S.S.G.), 38, 61-68.

RIBI, G. AND GEBHARDT, M. 1986. Age specific fecundity and size of offspring in the prosobranch snail, Viviparus ater. Oecologia , 71, 18-24.

RIBI, G. AND PORTER, A. H. 1995. Mating between two hybridizing species, Viviparus ater and $V$. contectus (Mollusca: Prosobranchia). Anim. Behav., 49, 1389-1398.

RIB1, G., MUTZNER, A. AND GEBHARDT, M. 1986. Shell dissolution and mortality in the freshwater snail Viviparus ater. Schweiz. Z. Hydrol., 48, 34-43.

SOKAL, R. R. AND ROHLf, F. J. 1995. Biometry. The Principles and Practice of Statistics in Biological Research, 3rd edn. Freeman, New York.

TRÜB, H. 1990. Züchtung von Hybriden zwischen Viviparus ater und V. contectus (Mollusca, Prosobranchia) im Zürichsee und ökologische Untersuchungen in einer gemischten Population im Gardasee. Ph.D. thesis, University of Zürich.

WhITE, M. J. D. 1978. Modes of Speciation. Freeman, San Francisco.

WU, C.-1., JOHNSON, N. A. AND PALOPOLI, M. F. 1996. Haldane's rule and its legacy: why are there so many sterile males? Trends Ecol. Evol., 11, 281-284. 